\title{
Online Medical Record Nonuse Among Patients: Data Analysis Study of the 2019 Health Information National Trends Survey
}

Safa Elkefi, MSc; Zhongyuan Yu, PhD; Onur Asan, PhD

School of Systems and Enterprises, Stevens Institute of Technology, Hoboken, NJ, United States

Corresponding Author:

Onur Asan, $\mathrm{PhD}$

School of Systems and Enterprises

Stevens Institute of Technology

1 Castle Point Terrace

Hoboken, NJ, 07030

United States

Phone: 14145264330

Email: oasan@stevens.edu

\section{Abstract}

Background: Online medical records are being used to organize processes in clinical and outpatient settings and to forge doctor-patient communication techniques that build mutual understanding and trust.

Objective: We aimed to understand the reasons why patients tend to avoid using online medical records and to compare the perceptions that patients have of online medical records based on demographics and cancer diagnosis.

Methods: We used data from the Health Information National Trends Survey Cycle 3, a nationally representative survey, and assessed outcomes using descriptive statistics and chi-square tests. The patients $(\mathrm{N}=4328)$ included in the analysis had experienced an outpatient visit within the previous 12 months and had answered the online behavior question regarding their use of online medical records.

Results: Patients who were nonusers of online medical records consisted of $58.36 \%$ of the sample (2526/4328). The highest nonuser rates were for patients who were Hispanic $(460 / 683,67.35 \%)$, patients who were non-Hispanic Black (434/653, 66.46\%), and patients who were older than 65 years $(968 / 1520,63.6 \%)$. Patients older than 65 years were less likely to use online medical records (odds ratio [OR] 1.51, 95\% CI 1.24-1.84, $P<.001$ ). Patients who were White were more likely to use online medical records than patients who were Black (OR 1.71, 95\% CI 1.43-2.05, $P<.001)$ or Hispanic (OR 1.65, 95\% CI 1.37-1.98, $P<.001)$. Patients who were diagnosed with cancer were more likely to use online medical records compared to patients with no cancer (OR 1.31, 95\% CI 1.11-1.55, 95\% CI 1.11-1.55, $P=.001)$. Among nonusers, older patients ( $\geq 65$ years old) preferred speaking directly to their health care providers (OR 1.76, 95\% CI 1.35-2.31, $P<.001$ ), were more concerned about privacy issues caused by online medical records (OR 1.79, 95\% CI 1.22-2.66, $P<.001$ ), and felt uncomfortable using the online medical record systems (OR 10.55, 95\% CI 6.06-19.89, $P<.001$ ) compared to those aged 18-34 years. Patients who were Black or Hispanic were more concerned about privacy issues (OR 1.42, 1.09-1.84, $P=.007$ ).

Conclusions: Studies should consider social factors such as gender, race/ethnicity, and age when monitoring trends in eHealth use to ensure that eHealth use does not induce greater health status and health care disparities between people with different backgrounds and demographic characteristics.

(J Med Internet Res 2021;23(2):e24767) doi: 10.2196/24767

\section{KEYWORDS}

online medical records; cancer; patient portals; communication; medical records; health information; eHealth

\section{Introduction}

Communication is a key element in providing high-quality health care services [1]. If communication is effective, it can lead to significant health care provision and positive outcomes, including decreased anxiety, guilt, pain, and disease symptoms. Moreover, effective communication can increase patient satisfaction, acceptance, adherence, and cooperation with the medical team, and it can improve the physiological and functional status of the patient [1]. Conversely, poor communication between doctors and patients can lead to poor 
quality and continuity of care [2]. Patients with communication-related disabilities or problems were 3 times more likely to experience medical or clinical complications compared to other patients [3]. Thus, ensuring good communication by recording, handling, and sharing health information with patients remains a necessity and an integral component of the health care process that may improve outcomes and limit or prevent costly duplication of tests and treatments $[4,5]$.

Information exchange is not only limited to the visit. It is moving beyond that, as patients have the opportunity to access their information regardless of location or time via technologies [4]. Technological advancement has provided opportunities not only to improve doctor-patient information exchange but also to inform and empower patients' role in decision making. Information and communication technology is often used for communication and information exchange purposes and may be a valuable tool for handling these challenges [6,7]. Other potential solutions include means for patients to access their online medical records, including personalized health records [8-11] and patient portals [12]. These centralized health information systems could also have the greatest benefit for information transmission. Although patient portals such as MyPreventiveCare [13], Ask an Expert [14], and others are considered important tools for the development of patient-centered care, their current use is not optimal, and portals are still less patient-centered than they could be [15-17]. Known barriers to the use of portals for patients and providers include security and privacy concerns, the potential negative impact on provider workflow, and limited user friendliness [12,18].

The ability of patients or individuals to access their online medical records serves as one of the backbones to improve patient engagement in and the outcomes of our health care system. Historically, patients have had low access to online medical records. For instance, only 3 out of 10 patients were offered access to medical records in 2013, and almost half of those offered access viewed their online records at least once
[19]. However, the use of online medical records has experienced significant growth in recent years, and technological improvements have been made to improve usability and implementation [20]. On the other hand, despite greater availability, there are many patients who still avoid using online medical records, though this may be changing with the current COVID-19 pandemic paradigm shift. The purpose of this study was to explore factors leading to the use or nonuse of online medical records across different groups of patients.

\section{Methods}

\section{Data Source}

Data for this study were derived from the National Cancer Institute's 2019 Health Information National Trends Survey (HINTS). HINTS is a nationally representative survey (of the US noninstitutionalized adult population) that collects data on the American public's need for, access to, and use of health-related information [21]. HINTS is publicly available on the web [22]. Data used in this study were from HINTS 5 Cycle 3 , collected between January and May of 2019. Patients who gave information about their online medical records use were included (survey response rate: 4328/14332, 30.20\%). Further details on survey design and sampling strategies are published elsewhere [23].

\section{Study Variables}

The following questions correspond to the measures used in the analysis of the study. The first question was, "How many times did you access your online medical record in the last 12 months?" We used this question to identify users and nonusers of online medical records. The respondents who reported accessing their medical record at least once were coded as users and respondents who reported accessing their records zero times were coded as nonusers. The primary population of interest of the study was nonusers. We specifically analyzed the responses of nonusers to the following questions (Table 1) regarding the reasons why they do not use online medical records.

Table 1. Questions for nonusers and corresponding factors.

\begin{tabular}{ll}
\hline Factor name & Question $^{\mathrm{a}}$ \\
\hline SpeakDirectly & You prefer to speak to your health care provider directly? \\
NoNeed & You did not have a need to use your online medical record? \\
ConcernedPrivacy & You were concerned about the privacy or security of your medical records' website? \\
NoRecord & You do not have an online medical record? \\
LogInProb & You found it difficult to login (for example, you had trouble remembering your password)? \\
Uncomfortable & You are not comfortable or experienced with computers? \\
MultipleRec & You have more than one online medical record? \\
\hline
\end{tabular}

${ }^{\mathrm{a}}$ All questions had binary (yes or no) responses.

\section{Data Analysis}

Descriptive statistics for the HINTS 5 Cycle 3 populations were generated for demographic variables (gender, age, race/ethnicity) and the cancer diagnosis variable. We investigated the relationship between the use of online medical records and the demographic or diagnosis variables using an unadjusted model-Fisher exact test. We focused on patients who had not used online medical records to better understand the reasons behind their avoidance of this particular technology. We report odds ratios (OR) and corresponding 95\% confidence intervals; 
statistical significance was determined based on $P<.05$. All analyses were conducted using $\mathrm{R}$ statistical software (version 3.6.3; packages: Ime4 and Stats).

\section{Results}

\section{Sample Characteristics}

HINTS 5 Cycle 3 had a total of 4328 respondents, and $57.74 \%$ of the respondents (2499/4328) were female. Most respondents were older than 50 years $(2926 / 4328,67.61 \%)$ and non-Hispanic White (2992/4328, 69.13\%), and 16\% of respondents (693/4328) had been diagnosed with cancer (Table 2 ).

Table 2. Demographic characteristics of the patients.

\begin{tabular}{ll}
\hline Characteristic & Respondents $(\mathrm{N}=4328), \mathrm{n}(\%)$ \\
\hline Gender & $1829(42.26)$ \\
$\quad$ Male & $2499(57.74)$ \\
Female & \\
Age (years) & $580(13.40)$ \\
$18-34$ & $822(18.99)$ \\
$35-49$ & $1406(32.49)$ \\
$50-64$ & $1520(35.12)$ \\
$\geq 65$ & \\
Race & $683(15.78)$ \\
Hispanic & $2992(69.13)$ \\
Non-Hispanic White & $653(15.09)$ \\
Non-Hispanic Black & \\
Cancer diagnosis & $693(16.01)$ \\
Have cancer & $3635(83.99)$ \\
No cancer & \\
\hline
\end{tabular}

\section{Use of Online Medical Records}

Among the 4328 respondents, 2526 (58.36\%) were nonusers. The ratio of nonusers across demographics ranged between $53 \%$ to $67 \%$, with patients who were Hispanic (460/683, 67.35\%) and patients who were non-Hispanic Black being highest
$(434 / 653,66.46 \%)$. Patients who were non-Hispanic White $(1360 / 2992,45.45 \%)$ and patients between 18 and 34 years of age had the highest online medical record use (269/580, $46.38 \%$ ). Table 3 presents percentages of users and nonusers across demographics and nonuser comparisons. 
Table 3. Use of online medical records.

\begin{tabular}{|c|c|c|c|c|c|}
\hline Characteristics & All, n (\%) & Nonuser, n (\%) & User, n (\%) & Odds ratio $(95 \% \mathrm{CI})$ & $P$ value \\
\hline All & 4328 & $2526(58.36)$ & $1802(41.64)$ & $\mathrm{N} / \mathrm{A}^{\mathrm{a}}$ & N/A \\
\hline \multicolumn{6}{|l|}{ Gender } \\
\hline Male & $1829(42.26)$ & $1130(61.78)$ & $699(38.22)$ & 1 & N/A \\
\hline Female & $2499(57.74)$ & $1396(55.86)$ & $1103(44.14)$ & $0.78(0.69-0.88)$ & $<.001$ \\
\hline \multicolumn{6}{|l|}{ Age (years) } \\
\hline $18-34$ & $580(13.40)$ & $311(53.62)$ & $269(46.38)$ & 1 & N/A \\
\hline $35-49$ & $822(18.99)$ & $450(54.74)$ & $372(45.26)$ & $1.04(0.84-1.30)$ & \\
\hline $50-64$ & $1406(32.49)$ & $797(56.69)$ & $609(43.31)$ & $1.13(0.92-1.38)$ & \\
\hline$\geq 65$ & $1520(35.12)$ & $968(63.68)$ & $552(36.32)$ & $1.51(1.24-1.84)$ & $<.001$ \\
\hline \multicolumn{6}{|l|}{ Race } \\
\hline Non-Hispanic White & $2992(69.13)$ & $1632(54.55)$ & $1360(45.45)$ & 1 & N/A \\
\hline Hispanic & $683(15.78)$ & $460(67.35)$ & $223(32.65)$ & $1.71(1.43-2.05)$ & $<.001$ \\
\hline Non-Hispanic Black & $653(15.09)$ & $434(66.46)$ & $219(33.54)$ & $1.65(1.37-1.98)$ & $<.001$ \\
\hline \multicolumn{6}{|l|}{ Cancer diagnosis } \\
\hline Have cancer & $693(16.01)$ & $365(52.67)$ & $328(47.33)$ & 1 & N/A \\
\hline No cancer & 3635 (83.99) & $2161(59.95)$ & $1474(40.05)$ & $1.31(1.11-1.55)$ & $<.001$ \\
\hline
\end{tabular}

${ }^{\mathrm{a}} \mathrm{N} / \mathrm{A}$ : not applicable.

Patients who avoided using online medical records were more likely to be male (OR $0.78,95 \%$ CI $0.69-0.88, P<.001)$. The oldest patients (aged $>65$ years) were less likely to use online medical records (OR 1.51, 95\% CI 1.24-1.84, $P<.001$ ). Patients who were non-Hispanic White were more likely to use online medical records than patients who were Hispanic (OR 1.71, 95\% CI 1.43-2.05, $P<.001$ ) or non-Hispanic Black (OR 1.65, $95 \%$ CI 1.37-1.98, $P<.001)$. Finally, patients diagnosed with cancer were more likely to use online medical records than patients without cancer (OR 1.31, 95\% CI 1.11-1.55, $P=.001$ ).

\section{Reasons for Nonuse of Online Medical Records}

In the second phase of the analysis, we only focused on nonusers $(n=2526)$ and explored factors regarding their preference for not using online medical records. We compared the different demographics for each factor. The survey had 7 listed factors asked to each respondent. Each participant responded to each question with "yes" or "no." We summarized the percentage for each demographic group among nonusers. The "desire to speaking directly to the health care provider" was the primary factor $(1575 / 2526,62.35 \%)$ influencing the nonuse of online medical records. Across all demographic characteristics, more than half of respondents answered "yes" for this question. For instance, $63.68 \%$ (889/1396) of female nonusers reported "desire to speaking directly" as one of the primary reasons. Almost half of the participants also expressed "no need" as a reason to avoid online medical records. The 18-34 years age group of nonusers had the highest rate of "no need" factor to explain their avoidance of online medical record use (194/311, 62.38\%). Privacy concerns were not a primary reason to avoid online medical record use across all groups (range $12 \%$ to $23 \%$ ). Table 4 illustrates all descriptive statistics for the overall nonuser population and each demographic group. 
Table 4. Frequencies of reasons that explain nonuse of online medical records.

\begin{tabular}{|c|c|c|c|c|c|c|c|}
\hline \multirow[t]{2}{*}{ Characteristic } & \multicolumn{7}{|l|}{ Factor, n (\%) } \\
\hline & SpeakDirectly & NoNeed & ConcernedPrivacy & NoRecord & LogInProb & Uncomfortable & MultipleRec \\
\hline All & $1575(62.35)$ & $1258(49.80)$ & $499(19.75)$ & $571(22.60)$ & $435(17.22)$ & $547(21.65)$ & $228(9.03)$ \\
\hline \multicolumn{8}{|l|}{ Gender } \\
\hline Male & $686(60.71)$ & $594(52.57)$ & $214(18.94)$ & $288(25.49)$ & $170(15.04)$ & $253(22.39)$ & $109(9.65)$ \\
\hline Female & $889(63.68)$ & $664(47.56)$ & $285(20.42)$ & $283(20.27)$ & $265(18.98)$ & $294(21.06)$ & $119(8.52)$ \\
\hline \multicolumn{8}{|l|}{ Age (years) } \\
\hline $18-34$ & $166(53.38)$ & $194(62.38)$ & $39(12.54)$ & $93(29.90)$ & $45(14.47)$ & $14(4.50)$ & $26(8.36)$ \\
\hline $35-49$ & $231(51.33)$ & $252(56.00)$ & $83(18.44)$ & $114(25.33)$ & $71(15.78)$ & $48(10.67)$ & $35(7.78)$ \\
\hline $50-64$ & $530(66.50)$ & $386(48.43)$ & $179(22.46)$ & $173(21.71)$ & $130(16.31)$ & $163(20.45)$ & $77(9.66)$ \\
\hline$\geq 65$ & $648(66.94)$ & $426(44.01)$ & $198(20.45)$ & $191(19.73)$ & $189(19.52)$ & $322(33.26)$ & $90(9.30)$ \\
\hline \multicolumn{8}{|l|}{ Race } \\
\hline $\begin{array}{l}\text { Non-Hispanic } \\
\text { White }\end{array}$ & $1004(61.52)$ & $922(56.50)$ & $289(17.71)$ & $375(22.98)$ & $294(18.01)$ & $334(20.47)$ & $164(10.05)$ \\
\hline Hispanic & $294(63.91)$ & $172(37.39)$ & $108(23.48)$ & $100(21.74)$ & $91(19.78)$ & $118(25.65)$ & $37(8.04)$ \\
\hline $\begin{array}{l}\text { Non-Hispanic } \\
\text { Black }\end{array}$ & $277(63.82)$ & $164(37.79)$ & $102(23.50)$ & $96(22.12)$ & $50(11.52)$ & 95 (21.89) & $27(6.22)$ \\
\hline \multicolumn{8}{|l|}{ Cancer diagnosis } \\
\hline Have cancer & $260(71.23)$ & $190(52.05)$ & $74(20.27)$ & $76(20.82)$ & $79(21.64)$ & $117(32.05)$ & $50(13.70)$ \\
\hline No cancer & $1315(60.85)$ & $1068(49.42)$ & $425(19.67)$ & $495(22.91)$ & $356(16.47)$ & $430(19.90)$ & $178(8.24)$ \\
\hline
\end{tabular}

The statistical analysis also yielded significant differences across the different demographics (Table 5 ). Older patients ( $\geq 65$ years old) were more likely to avoid using online medical records. They preferred speaking directly to their health care providers (OR 1.76, 95\% CI 1.35-2.31, $P<.001$ ), were more concerned about privacy issues caused by online medical records (OR
$1.79,95 \%$ CI 1.22-2.66, $P<.001)$, and felt uncomfortable using the systems (OR 10.55, 95\% CI 6.06-19.89, $P<.001$ ) compared to patients aged 18-34 years; however, they were more likely to be in need of online records (OR 0.47, 95\% CI 0.36-0.62, $P<.001)$. 
Table 5. Reasons for not using online medical records.

\begin{tabular}{|c|c|c|c|c|c|c|c|}
\hline \multirow[t]{2}{*}{ Characteristic } & \multicolumn{7}{|c|}{ Odds ratio $(95 \% \mathrm{CI})$} \\
\hline & SpeakDirectly & NoNeed & ConcernedPrivacy & NoRecord & LogInProb & Uncomfortable & MultipleRec \\
\hline \multicolumn{8}{|l|}{ Gender } \\
\hline Male & $\begin{array}{l}1.00(1.00- \\
1.00)\end{array}$ & $1.00(1.00-1.00)$ & $1.00(1.00-1.00)$ & $1.00(1.00-1.00)$ & $\begin{array}{l}1.00(1.00- \\
1.00)\end{array}$ & $1.00(1.00-1.00)$ & $1.00(1.00-1.00)$ \\
\hline Female & $\begin{array}{l}1.13(0.96- \\
1.33)\end{array}$ & $0.81(0.69-0.96)^{*}$ & $1.09(0.89-1.34)$ & $\begin{array}{l}0.74(0.61- \\
0.90)^{* * *}\end{array}$ & $\begin{array}{l}1.21(0.96- \\
1.54)\end{array}$ & $0.92(0.76-1.12)$ & $0.87(0.65-1.15)$ \\
\hline \multicolumn{8}{|l|}{ Age (years) } \\
\hline $18-34$ & $\begin{array}{l}1.00(1.00- \\
1.00)\end{array}$ & $1.00(1.00-1.00)$ & $1.00(1.00-1.00)$ & $1.00(1.00-1.00)$ & $\begin{array}{l}1.00(1.00- \\
1.00)\end{array}$ & $1.00(1.00-1.00)$ & $1.00(1.00-1.00)$ \\
\hline $35-49$ & $\begin{array}{l}0.92(0.68- \\
1.24)\end{array}$ & $0.76(0.56-1.04)$ & $1.57(1.02-2.44)^{*}$ & $0.79(0.56-1.11)$ & $\begin{array}{l}1.10(0.72- \\
1.70)\end{array}$ & $\begin{array}{l}2.53(1.34- \\
5.06)^{* *}\end{array}$ & $0.92(0.52-1.63)$ \\
\hline $50-64$ & $\begin{array}{l}1.73(1.31- \\
2.2)^{* * *}\end{array}$ & $\begin{array}{l}0.56(0.42- \\
0.74)^{* * * *}\end{array}$ & $2.01(1.37-3.01)$ & $\begin{array}{l}0.65(0.47- \\
0.88)^{* *}\end{array}$ & $\begin{array}{l}1.15(0.78- \\
1.70)\end{array}$ & $\begin{array}{l}5.44(3.08- \\
10.36)^{*}\end{array}$ & $1.17(0.72-1.94)$ \\
\hline$>65$ & $\begin{array}{l}1.76(1.35- \\
2.31)^{* * *}\end{array}$ & $\begin{array}{l}0.47(0.36- \\
0.62)^{* * *}\end{array}$ & $1.79(1.22-2.66)^{* *}$ & $0.57(0.42-0.77)^{*}$ & $\begin{array}{l}1.43(0.99- \\
2.09)\end{array}$ & $\begin{array}{l}10.55(6.06- \\
19.89) * * *\end{array}$ & $1.12(0.70-1.84)$ \\
\hline \multicolumn{8}{|l|}{ Race } \\
\hline $\begin{array}{l}\text { Non-Hispan- } \\
\text { ic White }\end{array}$ & $\begin{array}{l}1.00(1.00- \\
1.00)\end{array}$ & $1.00(1.00-1.00)$ & $1.00(1.00-1.00)$ & $1.00(1.00-1.00)$ & $\begin{array}{l}1.00(1.00- \\
1.00)\end{array}$ & $1.00(1.00-1.00)$ & $1.00(1.00-1.00)$ \\
\hline Hispanic & $\begin{array}{l}1.10(0.88- \\
1.38)\end{array}$ & $\begin{array}{l}0.46(0.36- \\
0.57)^{* * * *}\end{array}$ & $1.42(1.09-1.84)$ & $0.93(0.71-1.20)$ & $\begin{array}{l}1.12(0.85- \\
1.46)\end{array}$ & $\begin{array}{l}1.34(1.04-1.71) \\
*\end{array}$ & $0.78(0.52-1.14)$ \\
\hline $\begin{array}{l}\text { Non-Hispan- } \\
\text { ic Black }\end{array}$ & $\begin{array}{l}1.10(0.88- \\
1.38)\end{array}$ & $\begin{array}{l}0.46(0.37- \\
0.58)^{* * *}\end{array}$ & $1.42(1.09-1.84)$ & $0.95(0.72-1.23)$ & $\begin{array}{l}0.59(0.42- \\
0.82)^{* *}\end{array}$ & $1.08(0.83-1.41)$ & $\begin{array}{l}0.59(0.37- \\
0.91)^{*}\end{array}$ \\
\hline \multicolumn{8}{|l|}{ Cancer } \\
\hline Have cancer & $\begin{array}{l}1.00(1.00- \\
1.00)\end{array}$ & $1.00(1.00-1.00)$ & $1.00(1.00-1.00)$ & $1.00(1.00-1.00)$ & $\begin{array}{l}1.00(1.00- \\
1.00)\end{array}$ & $1.00(1.00-1.00)$ & $1.00(1.00-1.00)$ \\
\hline No cancer & $\begin{array}{l}0.62(0.48- \\
0.80)^{* * *}\end{array}$ & $0.90(0.71-1.13)$ & $0.96(0.72-1.28)$ & $1.12(0.85-1.50)$ & $\begin{array}{l}0.71(0.53- \\
0.95)^{*}\end{array}$ & $\begin{array}{l}0.52(0.41- \\
0.67)^{* * *}\end{array}$ & $\begin{array}{l}0.56(0.40- \\
0.80)^{* *}\end{array}$ \\
\hline
\end{tabular}

$* P<.05 ; * * P<.01 ; * * * P<.001$.

Female respondents were more likely to use online medical records, and they were more likely to have records (OR 0.74, $95 \%$ CI 0.61-0.90, $P=.003$ for female). Patients who were Black or Hispanic were more concerned about privacy issues (Black: OR 1.42, 95\% CI 1.09-1.84, $P=.007$; Hispanic: OR 1.42, 95\% CI 1.09-1.84, $P=.007)$ but were more conscious about the need for online records (Black: OR 0.46, 95\% CI 0.37-0.58, $P<.001$; Hispanic: OR $0.46,95 \%$ CI $0.36-0.57, P<.001)$. Patients who were Black were more likely to have problems logging in to their records (OR 0.59, 95\% CI 0.42-0.82, $P=.002$ ).

Patients with cancer preferred to speak directly to the health care providers (OR $0.62,95 \%$ CI $0.48-0.80, P<.001$ ) and were more likely to feel uncomfortable using online medical records (OR 0.52, 95\% CI 0.41-0.67, $P<.001$ ).

\section{Discussion}

\section{General}

Many studies that aim to improve information sharing and technology use in health care settings are based on exploring design improvements in patient-centered tools. Some discuss the environmental and technical barriers of adopting these tools $[12,18]$, and others focus on providing training to enhance use-related skills [24]. We used nationally representative data from 2019 and examined attitude and other factors influencing nonuse of online medical records across different groups of patients. The results portray trends just prior to the pandemic, which has undoubtedly precipitated a paradigm shift toward online and telehealth medical use since the beginning of 2020 .

The results showed that online medical record use was improving compared to use in previous years- $41 \%$ overall in 2019 compared to $28 \%$ in 2017 [25]. However, online medical record use was still only approximately $30 \%$ for older adults (65 years and above) and respondents who were Black or Hispanic. Older adults were less likely to use online medical records compared to younger patients. Previous studies have also found that those older than 65 years would be less likely to use the internet to find health information [26,27] and less likely to use electronic personal health records [28]. Another study [29,30] also demonstrated that older adults have rather negative attitudes toward computers. Patients who were Black or Hispanic in our sample were more likely to be nonusers of online medical records than patients who were White. This was consistent with the findings of a previous study [27] that collected data between 2010 and 2017; however, in our study, there were increased rates of online medical record use among 
minorities compared to those of previous years. Due to chronic underlying health conditions, adults aged $\geq 65$ years and individuals who are Black or Hispanic were the two groups hit hardest by the COVID-19 pandemic [31]. These groups often need continued care due to chronic health conditions [32]; however, visiting hospitals and clinics during the pandemic may increase the risk of infection. The online medical use rate would likely to be increased among these groups due to the pandemic.

In this study, we explicitly focused on the reasons people avoid online medical record use across demographics. The major reason that emerged from the data is that patients would prefer to "see their physicians in person." This was the primary reason for all groups except younger patients. Older patients were more likely to prefer to "speak in person with physicians" than younger patients. Furthermore, the preference to "speak in person with physicians" was also high for all race groups $(1575 / 2526,62.35 \%)$. These findings are not surprising since most patients value in-person visits with their doctors due to the more personal nature of the interaction, the opportunity to use nonverbal cues, and the ability to explain specific symptoms to doctors more clearly. Since March of 2020, however, the health care system is experiencing a paradigm shift due to an unprecedented pandemic, and telehealth visits have become a new normal, often replacing in-person visits, especially for older and chronically ill patients who are at high risk for COVID-19 infection. There is a tremendous rise in virtual care via telehealth technology during the pandemic [33]. Future studies will undoubtedly show changes in the demand for in-person visits after these forced experiences.

In the event of a population-wide infectious disease outbreak such as COVID-19, people's online activities may affect public concerns and health behaviors. Many studies [34,35] have explored people's active use of online information in various crises, including a public health crisis. The recent COVID-19 pandemic also sparked a paradigm shift in using online health care communication tools such as telehealth. It showed the importance and necessity of information sharing and communication beyond the walls of clinics.

The technology acceptance model explains that people use technologies when they are perceived as useful and necessary [36]. Almost half of the nonusers stated that there was no need for them to use online medical records. Young respondents (aged 18-34 years) among the sample were shown to be more likely to use online electronic medical records. Those who did not use online medical records in this group were likely to express that they had "no need" for their online medical record during this time period. This showed a significant difference compared to older patients $(P<.001)$. Intuitively, younger patients are healthier than older patients, but they also tend to be more comfortable using online health technologies. After the COVID-19 pandemic, a new necessity may emerge which also might influence young patients use of online medical records for any information exchange with their providers. Future HINTS data collected during or after the pandemic might also show this shift among young patients. Finally, respondents who were Black or Hispanic were less likely to state the reason of "no need" than respondents who were White.
Privacy has always been an issue for some users regarding the use of technologies for information sharing, especially information as sensitive and personal as medical records. Some participants also declared this as one of the factors for avoiding online medical record use. Respondents who were Black or Hispanic were more likely to have privacy concerns compared to those who were White. Historically, minorities have less trust in the health care system due to disparities they have experienced [24,37-39]. This might also influence their perception of privacy regarding any online health information exchange. Furthermore, older patients are highly likely to state "being uncomfortable using online record" as a reason for avoiding online medical records compared to younger patients. The US population had almost 52 million people older than 65 years as of 2018 [40]. This population will be the major consumer of health care systems for the foreseeable future; therefore, any online tools need to be redesigned to be user friendly (ie, for this population to use easily and comfortably).

Finally, our study also showed that patients with cancer use online medical records more than patients who do not have cancer. This was consistent with the findings of previous studies [41-43] showing that patients with such conditions may have a greater need for health tracking and sharing health information with multiple health care professionals than others. Among nonusers of online medical records, patients with cancer are likely to prefer speaking with physicians in person compared to patients who do not have cancer. The complexity of treatment options and the emotional aspect of visits make it more necessary for patients with cancer to meet with doctors in person. On the other hand, the health care system should have alternative plans to maintain quality online visits with these patients during the pandemic.

\section{Limitations}

This study also has limitations. First, the nature of HINTS data is cross-sectional and relies on subjective responses; therefore, it is not able to offer information on causality. Second, the low response rate (20\%-30\%) might raise some bias concerns, especially related to nonrespondents and sampling strategy. We should also note that the sampling and weighting strategy used by HINTS administrators helps minimize biases and improve national representativeness and generalizability of findings. Nonetheless, some local studies with more detail and a higher response rate should be conducted to validate the findings.

\section{Conclusion}

This study showed factors that lead people to avoid online medical record use across different demographics using a nationally representative survey. The findings show that there is an increased rate of online medical record use compared to previous years; however, this rate is still not at the expected level. The study shows that most patients still prefer speaking in person with their providers instead of using online medical records. Future studies should also look at how the education level of patients impacts these studied factors; our data did not have that component.

We also acknowledge that the recent COVID-19 pandemic has shifted the culture of virtual visits and online medical record 
use in health care. Future studies should look at online medical record use trends and factors during and after the pandemic to see how these have shifted. Finally, future designs and concepts of online medical communication technologies may also consider the importance of preparing a common ground for patients where different technology acceptance levels are respected.

\section{Acknowledgments}

Research reported in this publication was supported by the National Institute of Nursing Research of the National Institutes of Health (award number R15NR018965). The content is solely the responsibility of the authors and does not necessarily represent the official views of the National Institutes of Health.

\section{Conflicts of Interest}

None declared.

\section{References}

1. Norouzinia R, Aghabarari M, Shiri M, Karimi M, Samami E. Communication barriers perceived by nurses and patients. Glob J Health Sci 2015 Sep 28;8(6):65-74 [FREE Full text] [doi: 10.5539/gjhs.v8n6p65] [Medline: 26755475]

2. Scaioli G, Schäfer WLA, Boerma WGW, Spreeuwenberg P, van den Berg M, Schellevis FG, et al. Patients' perception of communication at the interface between primary and secondary care: a cross-sectional survey in 34 countries. BMC Health Serv Res 2019 Dec 30;19(1):1018 [FREE Full text] [doi: 10.1186/s12913-019-4848-9] [Medline: 31888614]

3. Bartlett G, Blais R, Tamblyn R, Clermont RJ, MacGibbon B. Impact of patient communication problems on the risk of preventable adverse events in acute care settings. CMAJ 2008 Jun 03;178(12):1555-1562 [FREE Full text] [doi: 10.1503/cmaj.070690] [Medline: 18519903 ]

4. van Walraven C, Taljaard M, Bell CM, Etchells E, Zarnke KB, Stiell IG, et al. Information exchange among physicians caring for the same patient in the community. CMAJ 2008 Nov 04;179(10):1013-1018 [FREE Full text] [doi: 10.1503/cmaj.080430] [Medline: 18981442]

5. de Lusignan S, Teasdale S, Little D, Zapp J, Zuckerman A, Bates D, et al. Comprehensive computerised primary care records are an essential component of any national health information strategy: report from an international consensus conference. Inform Prim Care 2004 Dec 01;12(4):255-264 [FREE Full text] [doi: 10.14236/jhi.v12i4.133] [Medline: 15808027]

6. Mukai TO, Bro F, Fenger-Grøn M, Olesen F, Vedsted P. Use of hyperlinks in electronic test result communication: a survey study in general practice. BMC Med Inform Decis Mak 2012 Oct 04;12(1):114 [FREE Full text] [doi:

10.1186/1472-6947-12-114] [Medline: 23035761]

7. Wennberg JE. Time to tackle unwarranted variations in practice. BMJ 2011 Mar 17;342(mar17 3):d1513-d1513. [doi: 10.1136/bmj.d1513] [Medline: 21415111]

8. Elbourne D, Richardson M, Chalmers I, Waterhouse I, Holt E. The Newbury Maternity Care Study: a randomized controlled trial to assess a policy of women holding their own obstetric records. Br J Obstet Gynaecol 1987 Jul;94(7):612-619. [doi: 10.1111/j.1471-0528.1987.tb03165.x] [Medline: 3304403]

9. Latimer EJ, Porterfield P, Roberts JG. A patient care travelling record for palliative care: a feasibility study. J Palliat Care 2019 Apr 08;7(2):30-36. [doi: 10.1177/082585979100700206]

10. Shah P, Selwyn B, Shah K, Kumar V. Evaluation of the home-based maternal record: a WHO collaborative study. Bull World Health Organ 1993;71(5):535-548 [FREE Full text] [Medline: 8261557]

11. van Wersch A, de Boer M, van der Does E, de Jong P, Knegt P, Meeuwis C, et al. Continuity of information in cancer care: evaluation of a logbook. Patient Educ Couns 1997 Jul;31(3):223-236. [doi: 10.1016/s0738-3991(97)00030-x]

12. Kruse CS, Argueta DA, Lopez L, Nair A. Patient and provider attitudes toward the use of patient portals for the management of chronic disease: a systematic review. J Med Internet Res 2015 Feb 20;17(2):e40 [FREE Full text] [doi: 10.2196/jmir.3703] [Medline: 25707035]

13. Krist AH, Woolf SH, Hochheimer C, Sabo RT, Kashiri P, Jones RM, et al. Harnessing information technology to inform patients facing routine decisions: cancer screening as a test case. Ann Fam Med 2017 May;15(3):217-224 [FREE Full text] [doi: 10.1370/afm.2063] [Medline: 28483886]

14. Lu H, Shaw BR, Gustafson DH. Online health consultation: examining uses of an interactive cancer communication tool by low-income women with breast cancer. Int J Med Inform 2011 Jul;80(7):518-528 [FREE Full text] [doi: 10.1016/j.ijmedinf.2011.03.011] [Medline: 21530381]

15. Otte-Trojel T, de Bont A, van de Klundert J, Rundall TG. Characteristics of patient portals developed in the context of health information exchanges: early policy effects of incentives in the meaningful use program in the United States. J Med Internet Res 2014 Nov 21;16(11):e258 [FREE Full text] [doi: 10.2196/jmir.3698] [Medline: 25447837]

16. Gerard M, Fossa A, Folcarelli PH, Walker J, Bell SK. What patients value about reading visit notes: a qualitative inquiry of patient experiences with their health information. J Med Internet Res 2017 Jul 14;19(7):e237 [FREE Full text] [doi: 10.2196/jmir.7212] [Medline: 28710055] 
17. Black H, Gonzalez R, Priolo C, Schapira MM, Sonnad SS, Hanson CW, et al. True "meaningful use": technology meets both patient and provider needs. Am J Manag Care 2015 May 01;21(5):e329-e337 [FREE Full text] [Medline: 26167781]

18. de Lusignan S, Mold F, Sheikh A, Majeed A, Wyatt JC, Quinn T, et al. Patients' online access to their electronic health records and linked online services: a systematic interpretative review. BMJ Open 2014 Sep 08;4(9):e006021 [FREE Full text] [doi: 10.1136/bmjopen-2014-006021] [Medline: 25200561]

19. Patel V, Barker W, Siminerio E. Individuals' access and use of their online medical record nationwide. ONC Data Brief 2014(20):1-12.

20. Demiris G. Consumer health informatics: past, present, and future of a rapidly evolving domain. Yearb Med Inform 2016 May 20;Suppl 1:S42-S47 [FREE Full text] [doi: 10.15265/IYS-2016-s005] [Medline: 27199196]

21. Nelson DE, Kreps GL, Hesse BW, Croyle RT, Willis G, Arora NK, et al. The Health Information National Trends Survey (HINTS): development, design, and dissemination. J Health Commun 2004 Sep;9(5):443-60; discussion 81. [doi: 10.1080/10810730490504233] [Medline: 15513791]

22. Health Information National Trends Survey. National Cancer Institute. 2019. URL: http://hints.cancer.gov/ [accessed 2020-09-09]

23. Finney RLJ, Davis T, Beckjord EB, Blake K, Moser RP, Hesse BW. Picking up the pace: changes in method and frame for the health information national trends survey (2011-2014). J Health Commun 2012;17(8):979-989 [FREE Full text] [doi: 10.1080/10810730.2012.700998] [Medline: 23020763]

24. Gordon NP, Hornbrook MC. Differences in access to and preferences for using patient portals and other ehealth technologies based on race, ethnicity, and age: a database and survey study of seniors in a large health plan. J Med Internet Res 2016 Mar 04;18(3):e50 [FREE Full text] [doi: 10.2196/jmir.5105] [Medline: 26944212]

25. Patel V, Johnson C. Individuals use of online medical records and technology for health needs. ONC Data Brief 2018(40):1-12.

26. Czaja SJ, Sharit J, Nair SN, Lee CC. Older adults and internet health information seeking. Proc Hum Factors Ergon Soc Annu Meet 2016 Nov 05;53(2):126-130. [doi: 10.1177/154193120905300204]

27. Asan O, Cooper II F, Nagavally S, Walker RJ, Williams JS, Ozieh MN, et al. Preferences for health information technologies among US adults: analysis of the Health Information National Trends Survey. J Med Internet Res 2018 Oct 18;20(10):e277 [FREE Full text] [doi: 10.2196/jmir.9436] [Medline: $\underline{\text { 30341048] }}$

28. Wen K, Kreps G, Zhu F, Miller S. Consumers' perceptions about and use of the internet for personal health records and health information exchange: analysis of the 2007 Health Information National Trends Survey. J Med Internet Res 2010 Dec;12(4):e73 [FREE Full text] [doi: 10.2196/jmir.1668] [Medline: 21169163]

29. Wandke H, Sengpiel M, Sönksen M. Myths about older people's use of information and communication technology. Gerontology 2012;58(6):564-570 [FREE Full text] [doi: 10.1159/000339104] [Medline: 22739502]

30. Czaja SJ, Charness N, Fisk AD, Hertzog C, Nair SN, Rogers WA, et al. Factors predicting the use of technology: findings from the Center for Research and Education on Aging and Technology Enhancement (CREATE). Psychol Aging 2006 Jun;21(2):333-352 [FREE Full text] [doi: 10.1037/0882-7974.21.2.333] [Medline: 16768579]

31. Clark A, Jit M, Warren-Gash C, Guthrie B, Wang HHX, Mercer SW, et al. Global, regional, and national estimates of the population at increased risk of severe COVID-19 due to underlying health conditions in 2020: a modelling study. Lancet Glob Health 2020 Aug;8(8):e1003-e1017. [doi: 10.1016/S2214-109X(20)30264-3]

32. Khera A, Baum S, Gluckman T, Gulati M, Martin S, Michos E, et al. Continuity of care and outpatient management for patients with and at high risk for cardiovascular disease during the COVID-19 pandemic: A scientific statement from the American Society for Preventive Cardiology. Am J Prev Cardiol 2020 Mar;1:100009 [FREE Full text] [doi: 10.1016/j.ajpc.2020.100009] [Medline: 32835347]

33. Wosik J, Fudim M, Cameron B, Gellad ZF, Cho A, Phinney D, et al. Telehealth transformation: COVID-19 and the rise of virtual care. J Am Med Inform Assoc 2020 Jun 01;27(6):957-962 [FREE Full text] [doi: 10.1093/jamia/ocaa067] [Medline: $\underline{32311034]}$

34. Gui X, Kou Y, Pine KH, Chen Y. Managing uncertainty: using social media for risk assessment during a public health crisis. 2017 Presented at: Conference on Human Factors in Computing Systems; May 6-11; Denver, Colorado p. $4520-4533$. [doi: 10.1145/3025453.3025891]

35. Rizo CA, Lupea D, Baybourdy H, Anderson M, Closson T, Jadad AR. What internet services would patients like from hospitals during an epidemic? Lessons from the SARS outbreak in Toronto. J Med Internet Res 2005 Aug 03;7(4):e46 [FREE Full text] [doi: 10.2196/jmir.7.4.e46] [Medline: 16236698$]$

36. Holden RJ, Asan O, Wozniak EM, Flynn KE, Scanlon MC. Nurses' perceptions, acceptance, and use of a novel in-room pediatric ICU technology: testing an expanded technology acceptance model. BMC Med Inform Decis Mak 2016 Dec 15;16(1):145 [FREE Full text] [doi: 10.1186/s12911-016-0388-y] [Medline: 27846827]

37. Goel MS, Brown TL, Williams A, Hasnain-Wynia R, Thompson JA, Baker DW. Disparities in enrollment and use of an electronic patient portal. J Gen Intern Med 2011 Oct;26(10):1112-1116 [FREE Full text] [doi: 10.1007/s11606-011-1728-3] [Medline: 21538166$]$

38. Smith SG, O'Conor R, Aitken W, Curtis LM, Wolf MS, Goel MS. Disparities in registration and use of an online patient portal among older adults: findings from the LitCog cohort. J Am Med Inform Assoc 2015 Jul;22(4):888-895 [FREE Full text] [doi: 10.1093/jamia/ocv025] [Medline: 25914099] 
39. Yamin CK, Emani S, Williams DH, Lipsitz SR, Karson AS, Wald JS, et al. The digital divide in adoption and use of a personal health record. Arch Intern Med 2011 Mar 28;171(6):568-574. [doi: 10.1001/archinternmed.2011.34] [Medline: 21444847]

40. Mather M, Scommegna P. Fact sheet: aging in the United States. Population Reference Bureau. URL: https://www.prb.org/ aging-unitedstates-fact-sheet/ [accessed 2020-10-10]

41. Wade-Vuturo AE, Mayberry LS, Osborn CY. Secure messaging and diabetes management: experiences and perspectives of patient portal users. J Am Med Inform Assoc 2013 May 1;20(3):519-525 [FREE Full text] [doi: 10.1136/amiajnl-2012-001253] [Medline: 23242764]

42. Kuwabara A, Su S, Krauss J. Utilizing digital health technologies for patient education in lifestyle medicine. Am J Lifestyle Med 2020 Dec 13;14(2):137-142 [FREE Full text] [doi: 10.1177/1559827619892547] [Medline: 32231478]

43. Baker JM, Grant RW, Gopalan A. A systematic review of care management interventions targeting multimorbidity and high care utilization. BMC Health Serv Res 2018 Jan 30;18(1):65 [FREE Full text] [doi: 10.1186/s12913-018-2881-8] [Medline: 29382327]

\section{Abbreviations \\ HINTS: Health Information National Trends Survey}

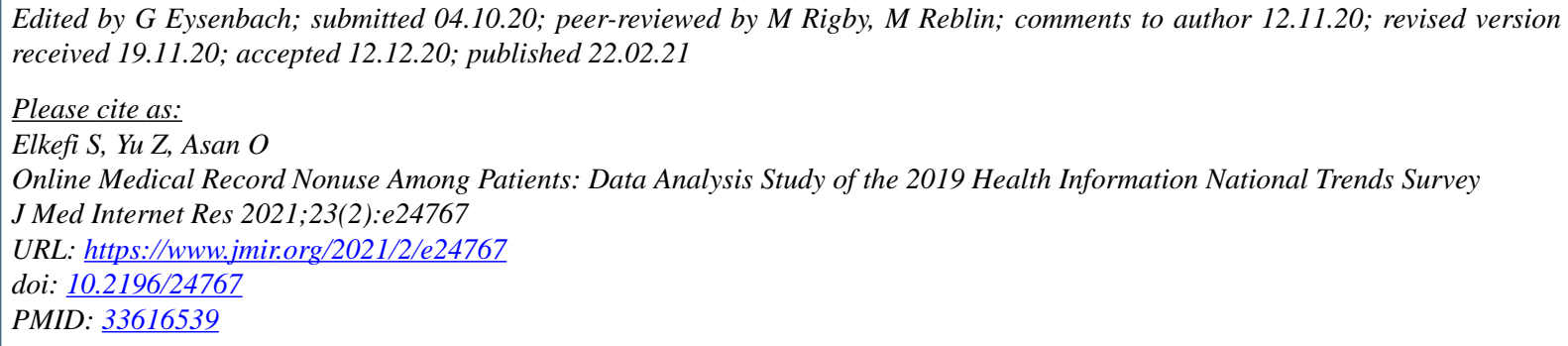

(CSafa Elkefi, Zhongyuan Yu, Onur Asan. Originally published in the Journal of Medical Internet Research (http://www.jmir.org), 22.02.2021. This is an open-access article distributed under the terms of the Creative Commons Attribution License (https://creativecommons.org/licenses/by/4.0/), which permits unrestricted use, distribution, and reproduction in any medium, provided the original work, first published in the Journal of Medical Internet Research, is properly cited. The complete bibliographic information, a link to the original publication on http://www.jmir.org/, as well as this copyright and license information must be included. 